\title{
Pengaruh Informasi Teknologi Terhadap Hubungan Antara Strategi Dan Kinerja Perusahaan
}

Dalam mencapai suatu strategi dan kinerja perusahaan yang diharapkan, tidak lepas dari pengaruh informasi teknologi (Chi, et al., 2017). Secara umum Informasi teknologi mampu mengintegrasikan, mengkomunikasikan, mempertukarkan berbagai aktivitas bisnis secara rinci. Hubungan antara Informasi teknologi dengan kinerja perusahaan terdapat tantangan tersendiri karena dengan adanya perubahan teknologi yang dapat diprediksi, perusahaan dapat memanfaatkan teknologi untuk melaksanakan strateginya. Informasi teknologi yang stabil memungkinkan perilaku proaktif untuk mencapai suatu kinerja yang baik, sedangkan perusahaan dengan perilaku proaktif akan mendapatkan kinerja yang buruk di bawah informasi teknologi yang dinamis. Informasi teknologi yang dinamis cenderung mendorong perusahaan untuk mengambil perilaku yang menghindari resiko dengan menetapkan strategi dengan orientasi berbasis sumber daya (Pratono, 2016). Dalam hal ini alangkah baiknya jika suatu perusahaan tidak hanya menitikberatkan fokusnya dalam memperoleh dan mengembangkan sumber daya tetapi juga perlunya meningkatkan informasi teknologi guna memfasilitasi aktivitas dalam kolaborasi elektronik.

References

Chi, et al. (2017). The influence of inter-firm IT governance strategies on relational performance: The moderation effect of information technology ambidexterity. International Journal of Information Management, 37 2017), 43-53.

Pratono. (2016). Strategic orientation and information technological turbulence Contingency perspective in SMEs. Business Process Management Journal, 377-379. 